\title{
Strong correspondence between nitrogen isotope composition of foliage and chlorin across a rainfall gradient: implications for paleo-reconstruction of the nitrogen cycle
}

\author{
Sara K. E. Goulden ${ }^{1}$, Naohiko Ohkouchi ${ }^{2}$, Katherine H. Freeman ${ }^{3}$, Yoshito Chikaraishi ${ }^{2}$, Nanako O. Ogawa ${ }^{2}$, \\ Hisami Suga $^{2}$, Oliver Chadwick ${ }^{4}$, and Benjamin Z. Houlton ${ }^{1}$ \\ ${ }^{1}$ University of California at Davis, Davis, CA 95616 USA \\ ${ }^{2}$ Japan Agency for Marine Earth-Science and Technology (JAMSTEC) Yokosuka, Kanagawa 237-0061, Japan \\ ${ }^{3}$ The Pennsylvania State University, University Park, State College, PA 16801, USA \\ ${ }^{4}$ University of California Santa Barbara, Santa Barbara, CA 93106, USA
}

Correspondence: Sara K. E. Goulden (skegoulden@gmail.com)

Received: 6 March 2019 - Discussion started: 23 April 2019

Revised: 1 August 2019 - Accepted: 13 August 2019 - Published: 8 October 2019

\begin{abstract}
Nitrogen (N) availability influences patterns of terrestrial productivity and global carbon cycling, imparting strong but poorly resolved feedbacks on Earth's climate system. Central questions concern the timescale of $\mathrm{N}$ cycle response to elevated $\mathrm{CO}_{2}$ concentration in the atmosphere and whether availability of this limiting nutrient increases or decreases with climate change. Nitrogen isotopic composition of bulk plant leaves provides information on large-scale patterns of $\mathrm{N}$ availability in the modern environment. Here we examine the utility of chlorins, degradation products of chlorophyll, hypothesized to persist in soil subsequent to plant decay, as proxies for reconstructing past plant $\delta^{15} \mathrm{~N}$. Specifically, we test the hypothesis that $\delta^{15} \mathrm{~N}$ of plant leaves ( $\delta^{15} \mathrm{~N}_{\text {leaf }}$ ) is recorded in $\delta^{15} \mathrm{~N}$ of pheophytin $a$ $\left(\delta^{15} \mathrm{~N}_{\text {pheo }}\right)$ along the leaf-litter-soil continuum across an array of ecosystem climate conditions and plant functional types $\left(\mathrm{C}_{3}, \mathrm{C}_{4}\right.$, legumes, and woody plants). The $\delta^{15} \mathrm{~N}$ of live foliage and bulk soil display marked declines with increasing rainfall, consistent with past studies in Hawaii and patterns worldwide. We find measurable chlorin concentrations along soil-depth profiles at all sites, with pheophytin $a$ present in amounts required for isotopic analysis (>10 nmol). $\delta^{15} \mathrm{~N}_{\text {pheo }}$ in leaves, litter, and soil track $\delta^{15} \mathrm{~N}_{\text {leaf }}$ of plant leaves. We find potential for $\delta^{15} \mathrm{~N}_{\text {pheo }}$ records from soil to provide proxy information on $\delta^{15} \mathrm{~N}_{\text {leaf }}$.
\end{abstract}

\section{Introduction}

A combination of high biological requirements, limited natural supply, and high chemical reactivity and mobility gives nitrogen $(\mathrm{N})$ important controls over photosynthesis and respiration in the terrestrial biosphere (Vitousek and Howarth, 1991). The response of the terrestrial carbon (C) cycle to climate change and increased atmospheric carbon dioxide $\left(p \mathrm{CO}_{2}\right)$ will depend largely on the availability of $\mathrm{N}$ (Hungate et al., 2003; Wang and Houlton, 2009; Ainsworth and Long, 2005; Denman et al., 2007; Thornton et al., 2009), raising the question of how $\mathrm{N}$ availability may also be expected to change.

Humans have modified the $\mathrm{N}$ cycle directly through production of reactive N (Galloway et al., 1995) and likely indirectly through several climate-induced changes receiving ongoing investigation, including changes in biological demand (McLauchlan et al., 2013), changes in organic mineralization (Durán et al., 2016) and mineral weathering rates (Houlton et al., 2018), and changes in N-fixation rates. Experimental manipulations have yielded tremendous insights into mechanisms underlying complex carbon-climate-N cycle dynamics, yet limitations of geography, complexity, and time have left open questions about the overall $\mathrm{N}$ biogeochemical response to climate change at the landscape and global scales.

Insight into actual outcomes on real landscapes over decadal to millennial timescales would be helpful to predict how feedbacks between $\mathrm{C}$ and $\mathrm{N}$ cycles will play a role in cli- 
mate change this century (Luo et al., 2004). If we could observe how $\mathrm{N}$ availability to plants responded to past periods of change in climate and $p \mathrm{CO}_{2}$, such as during transitions from glacial to interglacial periods, we could improve our projections for future integrative responses of the $\mathrm{N}$ cycles to a complex, changing world (Hungate et al., 2003; Houlton et al., 2015). Knowledge of past $\mathrm{N}$ cycle behavior would provide both insight into long-term dynamics and important baselines from which we can better assess anthropogenic impacts.

Natural abundance stable isotopes of $\mathrm{N}\left(\delta^{15} \mathrm{~N}\right)$ are useful integrators of $\mathrm{N}$ cycle processes in modern environmental systems (Robinson, 2001), and are natural sources of evidence for $\mathrm{N}$ cycle behavior in the past. Due to high reactivity and mobility of $\mathrm{N}$, point-based concentration measurements give temporally limited views of dynamic plantsoil-microbial cycling of N. $\delta^{15} \mathrm{~N}$ of plants and soils reflect a time-integrated signal of the $\mathrm{N}$ cycle. The gaseous loss processes (denitrification, ammonia volatilization, and anammox) which fractionate the light and heavy isotopes in terrestrial ecosystems are substrate-dependent, making $\delta^{15} \mathrm{~N}$ sensitive to changes in the availability of nitrogen (Houlton and Bai, 2009). Conversely, at low $\mathrm{N}$ availability, there is likely to be less isotopic expression of these pathways as well as potential for greater dependence of plants on ectomycorrhizae, thereby reducing isotopic difference between plant foliage and $\mathrm{N}$ sources (Hobbie and Ouimette, 2009). As a result, higher $\delta^{15} \mathrm{~N}_{\text {leaf }}$ corresponds to higher $\mathrm{N}$ availability to plants on average (e.g., Handley et al., 1999; Amundson et al., 2003; Houlton et al., 2007; Craine et al., 2009; Martinelli et al., 1999). Reconstructions of $\delta^{15} \mathrm{~N}_{\text {leaf }}$ would accordingly provide information on availability of $\mathrm{N}$ to plants in the past.

The same reactivity of $\mathrm{N}$ that makes $\delta^{15} \mathrm{~N}_{\text {leaf }}$ a valuable proxy for $\mathrm{N}$ availability in modern landscapes makes obtaining a primary $\mathrm{N}$ isotope signal from dead, buried, and decomposed organic matter particularly challenging. Primary $\delta^{15} \mathrm{~N}$ signatures are altered by decomposition and diagenesis (Thackeray, 1998; Meyers and Ishiwatari, 1993; Hedges and Oades, 1997), and bulk interpretations are confounded by preferential preservation and accumulation of macromolecules with distinct $\delta^{15} \mathrm{~N}$ values (Hobbie and Ouimette, 2009; Wedin et al., 1995). Because low-oxygen environments preserve organic matter, sediment accumulations in small lakes have been used as sources of terrestrial $\delta^{15} \mathrm{~N}_{\text {leaf }}$ (McLauchlan et al., 2013). However, lake ecosystem processes can obscure the original $\delta^{15} \mathrm{~N}$ of terrestrial sources (Meyers and Ishiwatari, 1993). Land-based paleoproxy $\delta^{15} \mathrm{~N}_{\text {leaf }}$ inferences have targeted bulk $\mathrm{N}$ protected structurally, in fossil faunal material (Stevens and Hedges, 2004), tree wood (Hietz et al., 2010), and pollen (DescolasGros and Scholzel, 2007). These approaches require controversial case-by-case defense of the primary nature of $\delta^{15} \mathrm{~N}$ due to diagenetic vulnerability (Harbeck et al., 2004; Thackeray, 1998) and redistribution of N (Gerhart and McLauchlan, 2014). In the case of faunal material, it is also necessary to consider species-specific trophic enrichment factors, age effects, and dietary protein content (Sponheimer et al., 2003; Overman and Parrish, 2001). Many of these approaches are further limited for understanding landscape-level patterns by the poor spatial distribution of samples.

Compound-specific isotope analysis (CSIA) of sedimentary material offers advantages over these methods: isotope ratios of individual compounds can be more resistant to diagenesis than those of bulk materials, and have the further advantages of deriving from more constrainable sources. This last characteristic permits analysis of material from integrative depositional environments. In marine $\mathrm{N}$ biogeochemistry, subaqueous sediments that collect and bury organic compounds in time series deposits are widely used for paleoenvironmental reconstruction (Junium et al., 2011; Meyers, 1997). Soils likewise accumulate organic material over time, though not perfectly analogously to subaqueous systems.

The ideal characteristic compound for CSIA reconstruction of $\delta^{15} \mathrm{~N}_{\text {leaf }}$ in soil is N-rich, produced only aboveground, and retains the primary $\delta^{15} \mathrm{~N}$ of plant leaves. We suggest that degradation products of the chlorophyll molecule (chlorins) meet all the above criteria. Chlorins derive from chlorophyll through processes of senescence, decomposition, diagenesis, and grazing (Keely, 2006; Treibs, 1936). They have been successfully extracted from plants, litter, organic soil layers, sediments, and coal deposits (Kennicutt et al., 1992; Sanger, 1971a; Hodgson et al., 1968; Bidigare et al., 1991; Dilcher et al., 1970), but have not previously been sought in mineral soil horizons.

$\delta^{15} \mathrm{~N}$ of chlorophyll and chlorins derived from algal pigments deposited in sediments have been used to infer $\mathrm{N}$ cycling processes in aquatic systems (Higgins et al., 2010; Sachs and Repeta, 1999; Enders et al., 2008; Tyler et al., 2010), as both combined chloropigment fractions and individual pigment compounds (Higgins et al., 2010; Kusch et al., 2010). Several studies have shown that the $\delta^{15} \mathrm{~N}$ of plant chlorophyll reflects bulk foliar $\delta^{15} \mathrm{~N}$ with a smaller offset than that between algal chlorophyll and bulk algal $\delta^{15} \mathrm{~N}$ (Chikaraishi et al., 2005; Bidigare et al., 1991; Kennicutt et al., 1992), but $\delta^{15} \mathrm{~N}$ has not previously been measured on chlorins extracted from decomposed plants, terrestrial organic matter, or soil. The behavior of chlorophyll $a$ degradation products and their $\delta^{15} \mathrm{~N}$ values along the leaf-soil continuum, and any environmental effects such as climate on isotope offsets, are also unknown.

Here we examine chlorin fractions for the presence of individual compounds in sufficient abundance for isotopic analysis. Pheophytin $a$ (pheo $a$ ) is a chlorin previously found in greater relative abundance than any other in organic soils and litter (Sanger, 1971a; Gorham and Sanger, 1967), and is therefore of particular interest. We next examine $\delta^{15} \mathrm{~N}$ of abundant chlorins in leaves, litter, and soil and compare values to bulk foliar sources to evaluate potential use of the compound as a proxy for past terrestrial foliar $\delta^{15} \mathrm{~N}$. For a chlorin to be a useful foliar $\delta^{15} \mathrm{~N}$ proxy in the terrestrial environment, 


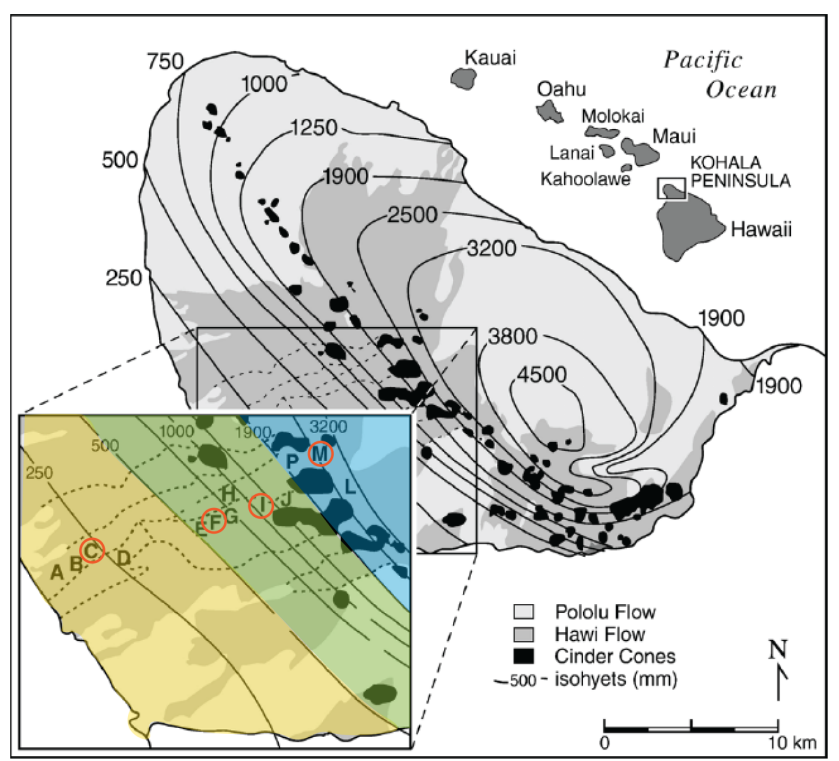

Figure 1. Map of Kohala climosequence sites with respect to rainfall isoclines, reproduced from Chadwick et al. (2007). Sites sampled for this study (C, F, I, and M) are circled in orange. Vegetation zones are highlighted in the inset map: lowland dry scrubland and grassland between 150 and $500 \mathrm{~mm}$ of rainfall (yellow); lowland dry and mesic forest, woodland, and shrubland from 500 to $2000 \mathrm{~mm}$ (green); and wet forest and woodland above $2000 \mathrm{~mm}$ (blue).

we hypothesize two conditions: first, it must persist in quantities sufficient for isotopic analysis. Second, it must record the $\delta^{15} \mathrm{~N}$ value of the leaves it derived from. To meet this second condition, the chlorin $\delta^{15} \mathrm{~N}$ must retain foliar $\delta^{15} \mathrm{~N}$ with at most a constrainable isotopic offset, independent of environmental conditions and throughout the processes of biosynthesis, senescence, and decomposition.

We evaluate these hypotheses on the natural climate gradient of the Kohala mountain, on the Big Island of Hawaii. These ecosystems are well suited for testing questions about relationships between climate, biogeochemistry, and the preservation or degradation of organic compounds. Relatively low plant diversity and broad environmental niches permit comparison of the bulk and compound-specific $\delta^{15} \mathrm{~N}$ of leaves, litter, and soil of similar grassland communities at sites ranging widely in climate and $\delta^{15} \mathrm{~N}$ to investigate patterns of deviation of compound-specific values from bulk values.

\section{Methods}

\subsection{Site description}

The four sites of this study are located on Kohala mountain, the oldest of five volcanoes that make up the Big Island of Hawaii (Fig. 1). The sites are a subset of a well characterized climosequence running from the crest of Kohala down the leeward side (see Chadwick et al., 2003; Kelly et al., 1998b; Vitousek and Chadwick, 2013; von Sperber et al., 2017). Prevailing winds from the northwest create a dramatic gradient in precipitation, from $2500 \mathrm{~mm}$ falling annually at the uppermost site to $210 \mathrm{~mm}$ at the lowest site (Giambelluca et al., 1986). In contrast to the substantial shift in precipitation, the elevation of the mountain produces only a moderate gradient in air temperature, ranging from $17^{\circ} \mathrm{C}$ at the upper site to $23^{\circ} \mathrm{C}$ at the lowest site. Soils have been forming since emplacement of the Hawaii lava flows, approximately 150000 years ago (Chadwick et al., 2003; Spengler and Garcia, 1988; Wolfe and Morris, 1996). This gradient thereby brings into focus precipitation as the most substantial systematic factor of change across sites.

Climate history for this region has been reconstructed from pollen assemblages in cores from bogs near the Kohala summit (Hotchkiss, 1998) and inferred from patterns of sea-level change (Ziegler et al., 2003), aeolian deposits (Porter, 1997), and soil calcite deposits at the drier sites (Chadwick et al., 2003; Porter, 1997). During glacial periods the summit was cooler and drier, while the lower sites show less climate variability, having remained arid throughout soil development.

Vegetation across the gradient was altered by clearing of land for pasture in the last 200 hundred years (Cuddihy and Stone, 1990; Chadwick et al., 2007), resulting in the introduction of non-native species and grasses with the $\mathrm{C}_{4}$ carboxylation pathway. All of the sites in this study experience grazing by cows, with sites F and I grazed most heavily. Site $\mathrm{C}$ is lowland dry scrubland and grassland ( 150 to $500 \mathrm{~mm}$ annual rainfall), dominated by buffel grass (Cenchrus ciliaria) and the leguminous tree keawe (Prosopis pallida). Sites F (790 $\mathrm{mm}$ annual rainfall) and I (1260 $\mathrm{mm}$ annual rainfall) lie in lowland dry and mesic forest, woodland, and shrubland zones, which through conversion to pasture are dominated by the grass kikuyu (Pennisetum clandestinum). Site M lies in the wet forest and woodland zone ( $2500 \mathrm{~mm}$ annual rainfall), in which ohia (Metrosideros polymorpha) is the dominant tree, and the native understory was previously dominated by tree fern (Cibotium spp.) and uluhe (Dicranopteris linearis), but conversion of land to pasture has introduced kikuyu and other species. The herbs clover (Desmodium incanum) and Madagascar ragwort (Senecio madagascariensis) were additionally prevalent at sites I and M.

\subsection{Sample collection and preparation}

Leaves were sampled across sites from six plant species, from the upper one-third of the canopy in the case of the trees: Two grasses, $P$. clandestinum and $C$. ciliaria; two herbs, D. incanum and S. madagascariensis; and two trees, P. pallida and M. polymorpha. Two of these species are $\mathrm{N}$ fixers (D. incanum and $P$. pallida), and two have a $\mathrm{C}_{4}$ carboxylation pathway (P. clandestinum and C. ciliaria) while the others have $\mathrm{C}_{3}$. Each species was collected wherever present within a radius of $\sim 50 \mathrm{~m}$ from the soil pit dug at 
each site, but not all species were present at all sites. For grasses and herbs, at least three individuals were collected at each site and bulked for processing as a single sample. For trees, leaves were collected from at least three branches per tree and bulked for processing.

Soils were sampled from pits dug in open, grassy areas with minimal slope. Pits were dug to a depth of greater than $50 \mathrm{~cm}$, with the deepest dug to $65 \mathrm{~cm}$. At these sites, litter and organic horizon layers were sampled as a single genetic horizon termed "litter," consisting of organic materials with fibrous through humic composition and which had a total thickness of less than $2 \mathrm{~cm}$. Mineral horizons were sampled at regular depth intervals of $\sim 10 \mathrm{~cm}$ to a depth of $50 \mathrm{~cm}$. Samples were bagged in Whirl-Pak bags and kept dark and chilled on ice in coolers until processing.

Live foliage was rinsed with deionized (DI) water to remove dust or other contaminants and then freeze-dried for preservation. Soils and litter were likewise freeze-dried. Dried samples were ground using either a carbide-steel shatter box (SPEX SamplePrep, University of California, Davis) or a mortar and pestle. Samples were stored in a dark freezer.

\subsection{Compound extraction and purification}

Samples were handled under very limited light conditions to minimize photodegradation. Pigments were extracted by sonication in triplicate using $\sim 100 \mathrm{~mL}$ of acetone $(300 \mathrm{~mL}$ total) for 1 to $80 \mathrm{~g}$ of subsamples. Extracts were concentrated by evaporation to near dryness under nitrogen or argon. The condensed acetone extract was partitioned between $10 \mathrm{~mL}$ hexane and $30 \mathrm{~mL}$ Milli-Q water via liquid-liquid extraction to remove more polar compounds. The hexane fraction was retrieved, and dried under gentle flow of argon gas, and this crude chlorophyll extract was dissolved in dimethylformamide and passed through a syringe filter $(0.4 \mu \mathrm{m})$ to remove particulates prior to high-pressure liquid chromatography (HPLC) chromatography.

Two-dimensional HPLC was used to separate and purify chlorophyll $a$ and $b$ and their photo-reactive degradation products (Agilent 1200 series with a diode-array detector (DAD) and a fraction collector). Sample fractions corresponding to peaks collected from the first HPLC column run were subsequently run through a second column for additional purification of individual compounds. For the first HPLC separation step using reversed phase, the sample was passed through a Zorbax Eclipse XDB C18 column $(9.4 \times 250 \mathrm{~mm} ; 5 \mu \mathrm{m})$ with a liquid phase consisting of acetonitrile/pyridine (100:0.5) and ethyl acetate/pyridine $(100: 0.5)$ in variable ratio, for $35 \mathrm{~min}$ at $4.2 \mathrm{~mL} \mathrm{~min}^{-1}$ and $30^{\circ} \mathrm{C}$, after Kusch et al. (2010). For the first $5 \mathrm{~min}$ of the run, acetonitrile/pyridine was $75 \%$ of the eluent, and this percentage was linearly reduced to $50 \%$ over the subsequent 30 min of the run. For all samples, pheophytin $a$ (pheo $a$ ) was collected upon elution at $\sim 19 \mathrm{~min}$. For five plant samples, chlorophyll $a$ and pyrochlorophyll $a$ were collected upon elution at $\sim 12 \mathrm{~min}$. Spectra were checked for purity across wavelengths $200-900 \mathrm{~nm}$. In the second HPLC separation step, also using the reverse phase, the sample was passed through an Agilent Zorbax Eclipse PAH column $(4.6 \times 250 \mathrm{~mm} ; 5 \mu \mathrm{m})$, with a liquid phase consisting of acetonitrile/pyridine $(100: 0.5)$ and ethyl acetate/pyridine $(100: 0.5)$ in a variable ratio for $35 \mathrm{~min}$ at a flow rate of $1 \mathrm{~mL} \mathrm{~min}{ }^{-1}$ and $15^{\circ} \mathrm{C}$. For the first $5 \mathrm{~min}$ of the run, acetonitrile/pyridine was $80 \%$ of the eluent, between 5 and $30 \mathrm{~min}$ this percentage was linearly reduced from $80 \%$ to $40 \%$, and for the last $5 \mathrm{~min}$ the column was flushed with $100 \%$ ethyl acetate/pyridine.

\subsection{Analytical methods}

Nitrogen isotopic composition, total $\mathrm{N}$, and total $\mathrm{C}$ analysis of bulk soil (including litter) and leaf samples was performed using an elemental analyzer interfaced to a continuous-flow isotope ratio mass spectrometer (EA-IRMS) at the University of California, Davis Stable Isotope Facility. The mean value of analytical precisions obtained for standard materials is $0.3 \%$ for $\delta^{15} \mathrm{~N}$. C/N ratios are reported in mass units. In the case of soil, analysis was performed on $20 \mathrm{mg}$ of material using an Elementar Vario EL Cube or MICRO Cube elemental analyzer (Elementar Analysensysteme GmbH, Hanau, Germany) interfaced to a PDZ Europa 2020 isotope ratio mass spectrometer (Sercon Ltd., Cheshire, $\mathrm{UK})$. In the case of leaves, analysis was performed on $\sim 4 \mathrm{mg}$ of material using a PDZ Europa ANCA-GSL elemental analyzer interfaced to a PDZ Europa 20-20 isotope ratio mass spectrometer (Sercon Ltd., Cheshire, UK). Samples are combusted at $1000^{\circ} \mathrm{C}$ in a reactor packed with copper oxide and lead chromate. Following combustion, oxides were removed in a reduction reactor (reduced copper at $650^{\circ} \mathrm{C}$ ). The helium carrier then flowed through a water trap (magnesium perchlorate). $\mathrm{N}_{2}$ and $\mathrm{CO}_{2}$ were separated using a molecular sieve adsorption trap (for soil) or Carbosieve gas chromatography (GC) column $\left(65^{\circ} \mathrm{C}, 65 \mathrm{~mL} \mathrm{~min}^{-1}\right)$ (for leaves) before entering the IRMS. Bulk isotopes of two plants (buffel and kikuyu samples from site F) were analyzed at the Japan Agency for Marine Earth-Science and Technology (JAMSTEC).

$\delta^{15} \mathrm{~N}$, total $\mathrm{N}$, and total $\mathrm{C}$ analysis of isolated pheo $a$ fraction was performed on a Nano EA-IRMS at JAMSTEC. This is a modification of an EA-IRMS system to achieve ultrasensitive analysis (Ogawa et al., 2010). All samples contained at minimum $10 \mathrm{nmol} \mathrm{N}$, resulting in $\delta^{15} \mathrm{~N}$ precision of $< \pm 0.4 \%$. To investigate the possibility of $\mathrm{N}$ contamination, nitrogenous volatile was analyzed for the pheo $a$ fraction using GC and a nitrogen-phosphorus detector (GC-NPD) with trimethylsilyl derivatization (BSTFA, Agilent Technologies, Palo Alto, CA) at JAMSTEC. C/N ratios from EA-IRMS were used as the "purity indicator" of each chlorophyll compound. As is described below, if a sample showed the clean spectrum pattern of a chlorin but had a significantly large $\mathrm{C} / \mathrm{N}$ ratio, it is likely that it contained $\mathrm{C}$-containing contam- 


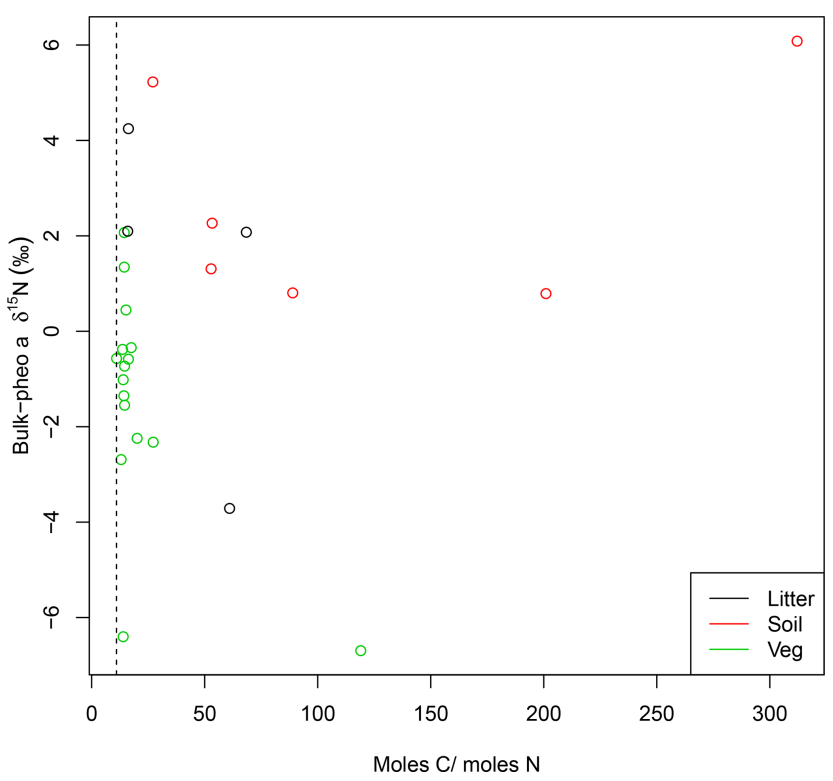

Figure 2. $\mathrm{C} / \mathrm{N}$ ratios for pheo $a$ isolates higher than 11 (dashed line) reveal contamination by carbon compounds. Effect of this contamination on pheo $a \delta^{15} \mathrm{~N}$ is investigated by comparing pheo $a$ molar $\mathrm{C} / \mathrm{N}$ with the offset between pheo $a$ and bulk $\delta^{15} \mathrm{~N}$ for litter (black), soil (red), and vegetation (green) samples. Lack of a systematic relationship between high $\mathrm{C} / \mathrm{N}$ ratios and greater similarity of pheo $a$ $\delta^{15} \mathrm{~N}$ to bulk values is evidence against contamination of the pheo $a$ samples by $\mathrm{N}$ from the greater bulk sample.

inants, such as carbon hydrates, which are not detectable by DAD.

\subsection{Purity of isolated compounds}

While absorption spectra in UV-visible wavelengths showed no evidence for other absorptive components in the pheo $a$ extracts, $\mathrm{C} / \mathrm{N}$ weight ratios greater than 11.8 revealed inclusion of non-pheo $a$ carbon in the extracts. $\mathrm{C} / \mathrm{N}$ ratios were higher in pheo $a$ extracted from litter (31) than plant samples (14.5), and even higher in pheo $a$ samples from soils (113). Lack of relationship between $\mathrm{C} / \mathrm{N}$ and bulk-pheo $\delta^{15} \mathrm{~N}$ offset suggests that impurities do not contribute significantly to measured $\delta^{15} \mathrm{~N}$ values, however (Fig. 2). This supposition was confirmed by results from the GC-NPD, which showed a lack of nitrogenous compounds (e.g., containing amino groups) in the pheo $a$ extracts. Although we caution that polar and less-volatile compounds cannot be detected by this method, the extraction methods make amino acids and other nitrogenous contaminants unlikely. The analytical protocol is designed to remove as many of such contaminating compounds as possible; e.g., amino acids are not soluble in acetone.
Table 1. Site averages, for all bulk samples. Percent $\mathrm{C}$ and $\mathrm{N}$ and $\mathrm{C} / \mathrm{N}$ are weight-based.

\begin{tabular}{lrrrrr}
\hline & C & F & I & M & $\begin{array}{r}\text { Site } \\
\text { average }\end{array}$ \\
\hline Precipitation (mm) & 210 & 790 & 1260 & 2500 & 1190 \\
\hline$\delta^{15} \mathrm{~N}_{\text {bulk leaf }}$ & 4.15 & 9.14 & 0.39 & 0.46 & 3.54 \\
$\delta^{15} \mathrm{~N}_{\text {bulk litter }}$ & 4.29 & 8.95 & 7.18 & 2.8 & 5.8 \\
$\delta^{15} \mathrm{~N}_{\text {bulk }}$ soil & 12.39 & 9.91 & 8.21 & 5.13 & 8.91 \\
\hline Soil \% C & 1.93 & 9.67 & 10.13 & 17.24 & 9.74 \\
Soil \% N & 0.17 & 0.83 & 0.95 & 1.19 & 0.78 \\
Soil C/N & 11.51 & 11.31 & 10.62 & 16.25 & 12.42 \\
\hline Litter \% C & 21.54 & 29.52 & 18.67 & 36.28 & 26.5 \\
Litter \% N & 1.38 & 1.94 & 1.48 & 1.44 & 1.56 \\
Litter C/N & 15.66 & 15.24 & 12.61 & 25.17 & 17.17 \\
\hline Veg \% C & 41.48 & 37.06 & 39.92 & 43.11 & 40.39 \\
Veg \% N & 2.69 & 2.65 & 2.32 & 2.28 & 2.49 \\
Veg C/N & 15.5 & 14.99 & 20.92 & 28.18 & 19.9 \\
\hline
\end{tabular}

\subsection{Isotopic notation}

Nitrogen isotopic compositions are reported using conventional delta $(\delta)$ notation:

$\delta(\% o)=\left(R_{\text {sample }} / R_{\text {standard }}-1\right) \times 1000$,

where $R$ represents the ${ }^{15} \mathrm{~N} /{ }^{14} \mathrm{~N}$ ratio and subscripts indicate the sample or isotopic reference. The sample isotopic composition is measured directly relative to the $\mathrm{N}_{2}$ laboratory reference gas $\left(\delta \mathrm{S}_{\mathrm{Ref}}\right)$, and the composition of the sample relative to the internationally recognized $\delta^{15} \mathrm{~N}$ reference, AIR, is calculated by

$\delta \mathrm{S}_{\mathrm{AIR}}=\delta \mathrm{S}_{\mathrm{Ref}}+\delta \operatorname{Ref}_{\mathrm{AIR}}+10^{-3} \delta \mathrm{S}_{\mathrm{Ref} \delta \operatorname{Ref}_{\mathrm{AIR}}}$.

Epsilon notation is used to describe biosynthetic isotopic fractionation within whole leaf (bulk) tissue. Nitrogen isotopic fractionation of pheo $a$ relative to bulk leaf tissue $\left({ }^{15} \varepsilon_{\text {pheo-leaf }}\right)$ and chlorophyll $a$ relative to bulk leaf tissue $\left({ }^{15} \varepsilon_{\text {chl-leaf }}\right)$ is defined according to Eq. (3):

${ }^{15} \varepsilon_{\text {compound-leaf }}=1000\left[\frac{\delta^{15} \mathrm{~N}_{\text {compound }}+1000}{\delta^{15} \mathrm{~N}_{\text {leaf }}+1000}-1\right]$.

\section{Results}

\subsection{Bulk isotope and $\mathrm{C}$ and $\mathrm{N}$ concentration data}

Site-averaged bulk $\delta^{15} \mathrm{~N}$ of all soil samples decreased with increasing precipitation (and elevation) across all sites, from an average of $12.4 \%$ at site $\mathrm{C}$ to $5.1 \%$ at site $\mathrm{M}$ (Table 1 ). Site-averaged $\delta^{15} \mathrm{~N}$ of litter decreased between sites $\mathrm{C}$ and 


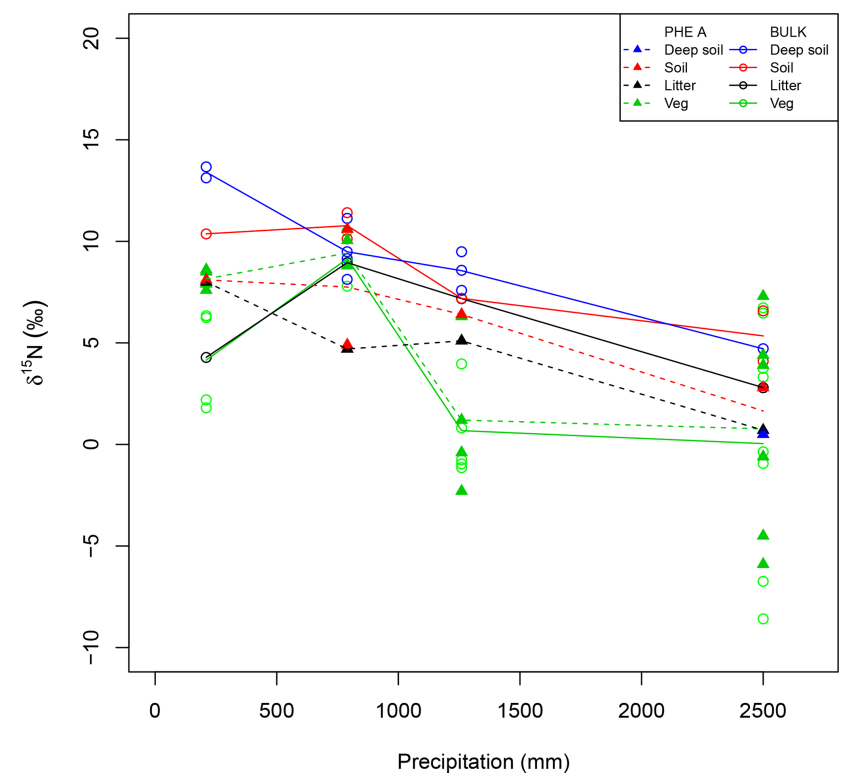

Figure 3. Patterns in isotopes of bulk material (open circles) and pheo $a$ extracts (closed triangles) from plant leaves (Veg, green), litter (black), and soil (red). Deep soils (blue) have a depth of greater than $30 \mathrm{~cm}$ and only one pheo $a$ isotope measurement was made for these samples. Lines connect site averages between bulk (solid) and pheo $a$ (dashed) measurements.

M (4.3\% to $2.8 \%$ ), but sites F and I were higher than either of these values $\left(9.0 \%\right.$ and $7.2 \%$ ). Average foliar $\delta^{15} \mathrm{~N}$ likewise decreased between sites $\mathrm{C}$ and $\mathrm{M}(4.2 \%$ to $0.5 \%$ ), but site F $(9.1 \%$ ) was higher than C (Fig. 3). Site-averaged bulk soil $\delta^{15} \mathrm{~N}$ values for those samples on which $\delta^{15} \mathrm{~N}_{\text {pheo }}$ was measured follow similar trends (Table 2), though on average site values are slightly lower ( $8.4 \%$ vs. $8.9 \%$ ), reflecting the shallower average depth of the soil samples.

Soil $\% \mathrm{~N}$ increased from site $\mathrm{C}(0.2 \%)$ to site $\mathrm{M}(1.2 \%)$, and $\% \mathrm{C}$ increased across these sites from $1.9 \%$ to $17.2 \%$. $\mathrm{C} / \mathrm{N}$ increased between these sites from 11.5 to 16.3 (Table 1). Litter $\% \mathrm{C}$ and $\mathrm{C} / \mathrm{N}$ was notably higher at site $\mathrm{M}$ (36.3\% and 25.2) than at the other sites, although litter \% N was relatively flat across all sites. Vegetation $\% \mathrm{C}$ was likewise highest at site $M(43.1 \%)$, though this value was less exceptional compared with vegetation at other sites.

Vegetation had the highest $\mathrm{C} / \mathrm{N}$ (average of 19.9), followed by litter (17.2) and soil (12.4). At sites C, F, and M, $\mathrm{C} / \mathrm{N}$ of litter is closer to that of vegetation than to soil, while at site I C/N of litter is closer to that of soil than to vegetation.

\subsection{Chlorin compound detection}

Chlorins were detected in leaf, litter, and soil samples, including in soil mineral horizons up to a depth of $32 \mathrm{~cm}$ (Table 2). As chlorophyll $a$ has greater absorbance at $660 \mathrm{~nm}$ than pheo $a$, direct proportionality between relative HPLC

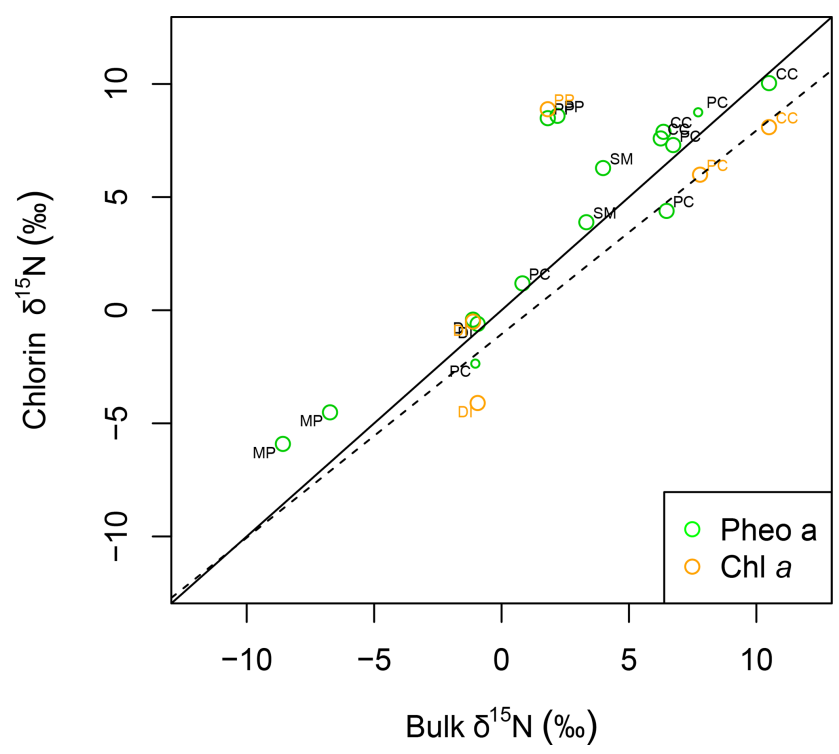

Figure 4. $\delta^{15} \mathrm{~N}$ of pheo $a$ (green) and chlorophyll $a$ (orange) correlates linearly with bulk leaf $\delta^{15} \mathrm{~N}$. The linear model for $\delta^{15} \mathrm{~N}$ of pheo $a$ as a function of bulk leaf $\delta^{15} \mathrm{~N}$ is printed as a dashed line. A line with a slope of 1 (solid line) is plotted for reference. Each sample's species is identified with a label: $\mathrm{CC}$ : $C$. ciliaria $\left(\mathrm{C}_{4}\right.$ pathway); DI: D. incanum (N fixer); MP: $M$. polymorpha (tree); PC: P. clandestinum $\left(\mathrm{C}_{4}\right.$ pathway); $\mathrm{PP}$ : P. pallida (N fixer, tree); $\mathrm{SM}$ : S. madagascariensis.

peak areas and relative compound abundance in the sample should not be assumed. In plant leaves, chlorophyll $a$ was the dominant chlorin. Chlorophyll $a$ was also found in smaller to trace amounts in litter and some soils. In litter, pheo $a$ was the dominant pigment, with the exception of site $\mathrm{M}$, where chlorophyll $a$ was more abundant in the litter sample. In site C, chlorophyll $a$ was absent from litter and soil. In soils, pheo $a$ was the most abundant degradation product. Pheo $a$, targeted for isotopic analysis due to its superlative abundance, was present in sufficient concentration for isotopic analysis above $\sim 20 \mathrm{~cm}$ in soils at most sites.

\subsection{Pheophytin $a \mathrm{~N}$ isotope data of leaves, litter, and soil}

Intra-leaf isotope offsets. Across all plant samples, $\delta^{15} \mathrm{~N}_{\text {pheo }}$ of live foliage was significantly linearly correlated with bulk $\delta^{15} \mathrm{~N}_{\text {leaf }}$ (slope $=0.9 ; \quad y$ intercept $=-1.1 ;$ adjusted $R^{2}=$ $0.8 ; p=0.000002507$ ) (Fig. 4). ${ }^{15} \varepsilon_{\text {pheo-leaf }}$ was equal to $1.4 \%$ o $( \pm 2.3 \% o)$ across all plant samples (Eq. 1).

Of the six sampled species, all but the two trees exhibited mean ${ }^{15} \varepsilon_{\text {pheo-leaf values }} \leq 1.5 \%$ o (Table 3 ): ${ }^{15} \varepsilon_{\text {pheo-leaf }}$ for P. pallida was $6.5 \%$ and ${ }^{15} \varepsilon_{\text {pheo-leaf }}$ for M. polymorpha was $2.5 \%$. If the $P$. pallida sample is omitted, ${ }^{15} \varepsilon_{\text {pheo-leaf }}$ drops to $0.71 \%$ o $( \pm 1.3 \%$ o.

${ }^{15} \varepsilon_{\text {pheo-leaf }}$ was largest at site C $(4.0 \%$ o) and smallest at site $\mathrm{F}(0.12 \%)$. For a given species, average ${ }^{15} \varepsilon_{\text {pheo-leaf }}$ 
Table 2. Relative compound abundance in a plant sample and the litter and soil horizons on which $\delta^{15} \mathrm{~N}_{\text {pheo }}$ was measured, grouped by site. Values reported are summed peak areas of absorbance at $660 \mathrm{~nm}$ in units of milli-absorbance units, summed for all collected injections of the sample. Values are first reported for individual compounds and then compared with the summed area of all detected chlorin peaks, first as absolute values and then as a percentage of chlorin peak area. Chlorophyll is abbreviated Chl.

\begin{tabular}{|c|c|c|c|c|c|c|c|c|}
\hline Site & Name & Chl $b$ & $\mathrm{Chl} a^{\mathrm{a}}$ & Pheo $b$ & Pheo $a$ & Sum All & $\%$ Pheo $a$ & $\%$ Chl $a^{\mathrm{a}}$ \\
\hline \multirow{3}{*}{$\mathrm{C}$} & C. ciliaria & 22119 & 81074 & 39 & 52545 & 260225 & 44 & 62 \\
\hline & Litter/O & & & & 5173 & 9622 & 54 & 0 \\
\hline & $00-16$ & & & & 3225 & 5178 & 62 & 0 \\
\hline \multirow{4}{*}{$\mathrm{F}$} & P. clandestinum & 3980 & 36469 & & 21452 & 75487 & 28 & 48 \\
\hline & Litter/O & 525 & 5496 & & 4625 & 14995 & 31 & 37 \\
\hline & 03-08 & & 559 & & 2483 & 4391 & 57 & 13 \\
\hline & $08-13$ & & 1104 & & 1590 & 3687 & 43 & 30 \\
\hline \multirow{3}{*}{ I } & S. madagascariensis & 15264 & 92967 & & 4106 & 144176 & 3 & 64 \\
\hline & Litter/O & & 855 & & 2820 & 10036 & 28 & 9 \\
\hline & $00-10$ & & & 225 & 1058 & 1711 & 62 & 0 \\
\hline \multirow{4}{*}{ M } & D. incanum & 1146 & 9385 & & 2432 & 16299 & 15 & 58 \\
\hline & Litter/O & 276 & 1260 & & 963 & 2952 & 33 & 43 \\
\hline & $00-15$ & & & 2357 & 7437 & 13698 & 54 & 0 \\
\hline & $24-32$ & & & 88 & 332 & 656 & 51 & 0 \\
\hline
\end{tabular}

${ }^{\text {a }}$ Chlorophyll $a$ and pyrochlorophyll $a$ are combined.

Table 3. Average, minimum, maximum, and range of intra-leaf $\delta^{15} \mathrm{~N}$ offsets between pheo $a$ and bulk ( $\left.{ }^{15} \varepsilon_{\text {pheo-leaf }}\right)$ for $n$ measurements of each sampled species across all sites.

\begin{tabular}{|c|c|c|c|c|c|}
\hline & Mean $\varepsilon$ & $\operatorname{Min} \varepsilon$ & $\operatorname{Max} \varepsilon$ & Range & $n$ \\
\hline C. ciliaria $^{\mathrm{a}}$ & 0.81 & -0.45 & 1.54 & -1.99 & 3 \\
\hline P. clandestinum $^{\mathrm{a}}$ & -0.29 & -2.06 & 1 & -3.06 & 5 \\
\hline P. pallida ${ }^{\mathrm{b}, \mathrm{c}}$ & 6.53 & 6.39 & 6.68 & -0.29 & 2 \\
\hline D. incanum ${ }^{\mathrm{b}}$ & 0.54 & 0.34 & 0.73 & -0.39 & 2 \\
\hline S. madagascariensis & 1.44 & 0.58 & 2.31 & -1.73 & 2 \\
\hline M. polymorpha ${ }^{\mathrm{c}}$ & 2.48 & 2.26 & 2.71 & -0.46 & 2 \\
\hline
\end{tabular}

${ }^{a} \mathrm{C}_{4}$ pathway. ${ }^{\mathrm{b}} \mathrm{N}$ fixer. ${ }^{\mathrm{c}}$ Tree.

tended to either remain flat or slightly decrease into the wettest sites (Fig. 5).

$\delta^{15} N_{\text {pheo }}$ offsets across leaf-litter-soil. $\delta^{15} \mathrm{~N}$ of pheo $a$ in litter was on average $0.3 \%$ o higher than the $\delta^{15} \mathrm{~N}$ of pheo $a$ of live foliage at a common site. Average differences between the $\delta^{15} \mathrm{~N}$ of bulk litter and foliage were slightly higher, at $\sim$ $2.6 \%$ at a common site (Table 4). Pheo $a$-specific soil $\delta^{15} \mathrm{~N}$ values were on average $1.3 \%$ o higher than pheo $a$ litter values at a common site; bulk $\delta^{15} \mathrm{~N}$ soil values are $2.6 \%$ o higher than bulk litter. The average offset between $\delta^{15} \mathrm{~N}_{\text {pheo }}$ of soil and live foliage at a site was $1.1 \%$; the average offset between bulk soil and bulk vegetation $\delta^{15} \mathrm{~N}$ was $4.9 \%$.

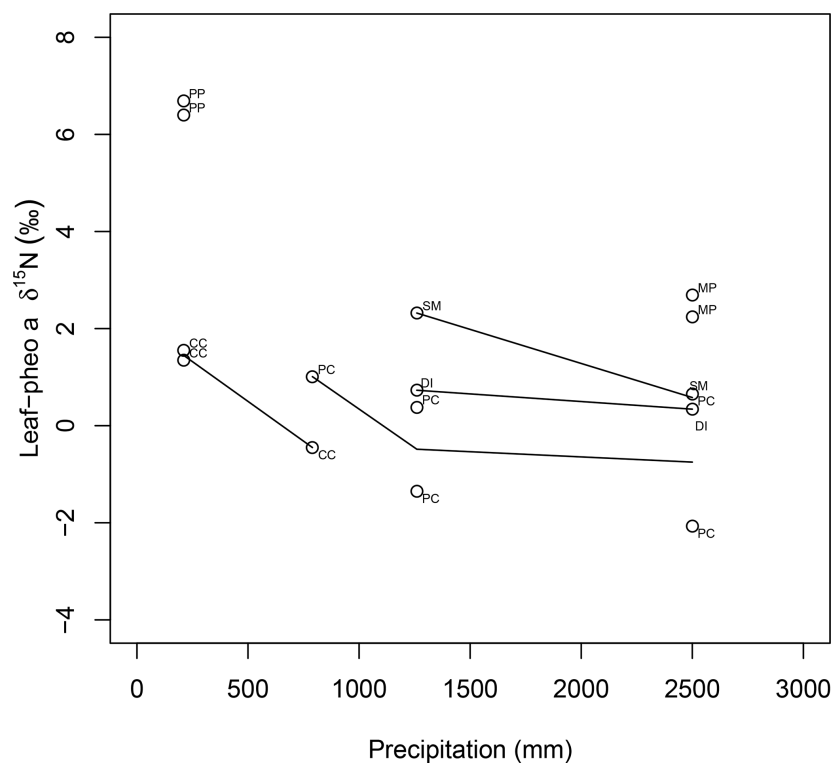

Figure 5. Comparison of species average intra-leaf $\delta^{15} \mathrm{~N}$ offset between pheo $a$ and bulk ( $\left.{ }^{15} \varepsilon_{\text {pheo-leaf }}\right)$ across sites. CC: $C$. ciliaria ( $\mathrm{C}_{4}$ pathway); DI: D. incanum (N fixer); MP: M. polymorpha (tree); PC: P. clandestinum ( $\mathrm{C}_{4}$ pathway); PP: P. pallida (N fixer, tree); SM: S. madagascariensis. 
Table 4. Isotope values, offsets between bulk and pheo $a \delta^{15} \mathrm{~N}$ values, and differences in pheo $a$ and bulk $\delta^{15} \mathrm{~N}$ values across the leafsoil continuum, across sites. Bulk values are included only for samples for which a corresponding pheo $a$ measurement was made.

\begin{tabular}{lrrrrr}
\hline & C & F & I & M & $\begin{array}{r}\text { Site } \\
\text { average }\end{array}$ \\
\hline$\delta^{15} \mathrm{~N}_{\text {bulk leaf }}$ & 4.15 & 9.14 & 0.68 & 0.04 & 3.5 \\
$\delta^{15} \mathrm{~N}_{\text {pheo leaf }}$ & 8.15 & 9.43 & 1.2 & 0.77 & 4.89 \\
\hline$\delta^{15} \mathrm{~N}_{\text {bulk litter }}$ & 4.29 & 8.95 & 7.18 & 2.8 & 5.8 \\
$\delta^{15} \mathrm{~N}_{\text {pheo litter }}$ & 8 & 4.7 & 5.1 & 0.7 & 4.62 \\
\hline$\delta^{15} \mathrm{~N}_{\text {bulk soil }}$ & 10.37 & 10.77 & 7.19 & 5.35 & 8.42 \\
$\delta^{15} \mathrm{~N}_{\text {pheo }}$ soil & 8.1 & 7.75 & 6.4 & 1.65 & 5.97 \\
\hline$\varepsilon$ pheo-leaf & 3.99 & 0.28 & 0.52 & 0.73 & 1.44 \\
\hline$\Delta_{\text {phe veg-litter }}$ & 0.15 & 4.73 & -3.9 & 0.07 & 0.26 \\
$\Delta_{\text {bulk veg-litter }}$ & -0.14 & 0.2 & -6.5 & -2.76 & -2.3 \\
\hline$\Delta_{\text {phe litter-soil }}$ & -0.1 & -3.05 & -1.3 & -0.95 & -1.35 \\
$\Delta_{\text {bulk litter-soil }}$ & -6.08 & -1.82 & -0.01 & -2.55 & -2.61 \\
\hline$\Delta_{\text {phe leaf-soil }}$ & 0.05 & 1.68 & -5.2 & -0.88 & -1.09 \\
$\Delta_{\text {bulk }}$ leaf-soil & -6.22 & -1.62 & -6.51 & -5.3 & -4.91 \\
\hline
\end{tabular}

\subsection{Soil depth profiles}

Soil $\delta^{15} \mathrm{~N}_{\text {bulk }}$ was, on average, higher than the $\delta^{15} \mathrm{~N}_{\text {bulk }}$ of overlying litter, and there was a slight trend of increasing $\delta^{15} \mathrm{~N}_{\text {bulk }}$ with increasing depth in the upper $\sim 25 \mathrm{~cm}$ of soil pits (Fig. 6). $\delta^{15} \mathrm{~N}_{\text {pheo }}$ of soil also displayed higher values relative to overlying litter at sites $\mathrm{F}$ and $\mathrm{I}$ and in part of the profile at site $\mathrm{M}$ (Fig. 6). Soil $\delta^{15} \mathrm{~N}_{\text {bulk values returned to }}$ slightly more negative values deep in the profiles; particularly notable at site F. At site $\mathrm{C}, \delta^{15} \mathrm{~N}_{\text {pheo }}$ values along the soil profile do not deviate significantly from that of the overlying litter. At site $\mathrm{M}, \delta^{15} \mathrm{~N}_{\text {pheo }}$ values increased slightly with depth in the upper profile, but then decreased while $\delta^{15} \mathrm{~N}_{\text {bulk }}$ steadily increased with greater depth. In sum, $\delta{ }^{15} \mathrm{~N}_{\text {pheo }}$ of soil did not follow $\delta^{15} \mathrm{~N}_{\text {bulk }}$, nor did it constantly track $\delta^{15} \mathrm{~N}_{\text {pheo }}$ of modern plants at a common site.

\section{Discussion}

\subsection{Evaluation of $\delta^{15} \mathrm{~N}$ fractionation within leaves}

Nitrogen isotopic offsets between pheophytin $a$ and live foliage $\left({ }^{15} \varepsilon_{\text {pheo-leaf }}\right)$ are generally small (mean of $1.4 \%$ ) and well constrained (SD $\pm 2.3 \%$, Fig. 3) across our sites, marking $\delta^{15} \mathrm{~N}_{\text {pheo }}$ as a useful proxy for bulk $\delta^{15} \mathrm{~N}_{\text {leaf }}$. The robustness of ${ }^{15} \varepsilon_{\text {pheo-leaf }}$ across the wide range in environmental variables and values of $\delta^{15} \mathrm{~N}_{\text {leaf }}$ observed across these sites (Fig. 4) suggests that isotope effects from species or physiological changes will be relatively small sources of variation in $\delta^{15} \mathrm{~N}_{\text {pheo }}$ compared with changes to primary $\delta^{15} \mathrm{~N}_{\text {leaf }}$. For

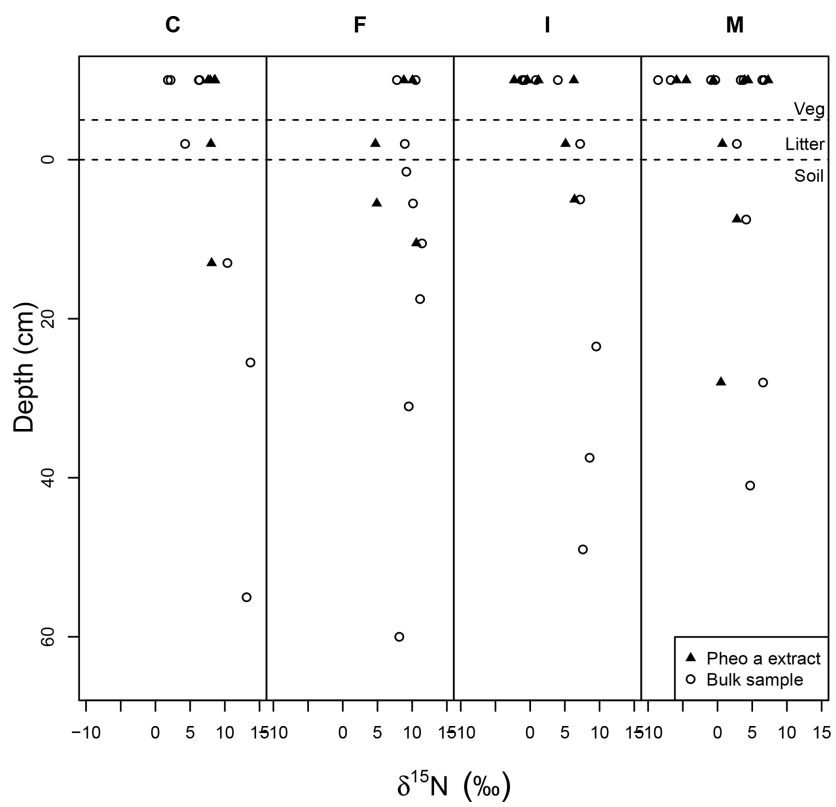

Figure 6. Bulk samples (open circles) and pheo $a$-specific (closed triangles) $\delta^{15} \mathrm{~N}$ in depth profiles across the rainfall gradient from dry (C) to wet (M) sites. Dashed lines set apart the vegetation samples (top) from litter samples (middle) and soil samples (bottom). The surface of the mineral soil is at a depth of 0 .

example, average community foliar $\delta^{15} \mathrm{~N}_{\text {leaf }}$ varies by about $\sim 10 \%$ across terrestrial biomes in the modern environment (Craine et al., 2009), and paleo records have inferred comparable shifts in $\delta^{15} \mathrm{~N}_{\text {leaf }}$ of $10 \%$ between glacial-interglacial cycles (Stevens et al., 2008). The possible effect of species shifts, and particularly growth of forests, should be considered when evaluating proxy $\delta^{15} \mathrm{~N}_{\text {pheo }}$ records, however. One species, P. pallida, has ${ }^{15} \varepsilon_{\text {pheo-leaf }}$ of $6.5 \%$. The other tree studied here, M. Polymorpha, had the next largest ${ }^{15} \varepsilon_{\text {pheo-leaf }}$ $(2.5 \%$ ) , while herbaceous plant values were all considerably smaller ( -0.29 to $1.4 \%$ ), raising the possibility that this is a systematic isotope effect in trees, perhaps due to their greater size, longevity, and resulting $\mathrm{N}$ storage and redistribution requirements relative to herbaceous plants.

\subsection{Evaluation of $\delta^{15} \mathrm{~N}_{\text {pheo }}$ from soil as a proxy for $\delta^{15} \mathrm{~N}_{\text {leaf }}$}

Pheo $a$ was present in quantities sufficient for isotopic analysis in litter and the uppermost mineral soil sample at all sites, and down to $30 \mathrm{~cm}$ at the wettest site (Fig. 4), inviting exploration of soil $\delta^{15} \mathrm{~N}_{\text {pheo }}$ as a proxy for $\delta^{15} \mathrm{~N}_{\text {leaf. }} \delta^{15} \mathrm{~N}_{\text {pheo }}$ of soil and litter matches $\delta^{15} \mathrm{~N}_{\text {pheo }}$ of overlying leaves at only one studied site (site $\mathrm{C}$ ). Two alternatives could explain the lack of coherence in leaf, litter, and soil pools across most sites: (1) there is isotopic alteration during senescence and mineralization of chlorophyll, and (2) litter and soil pheo $a$ pools have other sources than the plants we sampled, either on the current landscape or from previous vegetation covers. 
To investigate the expression of fractionation on demetallation of chlorophyll in these samples, we can compare the $\delta^{15} \mathrm{~N}_{\text {pheo }}$ with chlorophyll $a$ from the same sample. Chlorophyll $a$ was only in sufficient abundance for isotopic measurement in live plant leaves. Chlorophyll $a$ is about $0.05 \%$ o depleted in ${ }^{15} \mathrm{~N}$ relative to bulk leaves in this study. This is consistent with previous studies, which found chlorophyll in plants to be $1.2 \%$ o depleted in ${ }^{15} \mathrm{~N}$ relative to bulk leaf tissue (Kennicutt et al., 1992; Chikaraishi et al., 2005). Pheo $a$ is accordingly about $2 \%$ enriched in ${ }^{15} \mathrm{~N}$ relative to chlorophyll $a$ in our leaf samples, which could point to fractionation either within the leaf or in the laboratory (Sachs, 1997). Because chlorophyll abundance is greatly reduced between leaves and litter, any fractionation is likely to be expressed as a difference between leaves and litter, not as a difference between litter and soil or within soil. Fractionation on demetallation from chlorophyll should therefore not account for changes in $\delta^{15} \mathrm{~N}_{\text {pheo }}$ in the soil.

Soil is enriched in ${ }^{15} \mathrm{~N}$ relative to litter at our sites, consistent with observations from a wide range of environments, including temperate rainforest (Menge et al., 2011), temperate deciduous forests (Templer and Dawson, 2004), boreal forests (Hyodo and Wardle, 2009), tropical forests (Martinelli et al., 1999), temperate grasslands (Baisden et al., 2002; Brenner et al., 2001), and elsewhere (Hobbie and Ouimette, 2009). Because post-depositional processing of $\mathrm{N}$ involves the preferential loss of ${ }^{14} \mathrm{~N}$ from the soil $\mathrm{N}$ pool without replacement, through removal of the products of mineralization and denitrification, bulk soil $\delta^{15} \mathrm{~N}$ is highly dynamic and will tend to increase along a decomposition gradient. In contrast, if there is no fractionation on breakdown of pheo $a, \delta^{15} \mathrm{~N}_{\text {pheo }}$ in soil should not depart from the $\delta^{15} \mathrm{~N}_{\text {pheo }}$ of litter inputs.

In soil profiles across the climosequence, $\delta^{15} \mathrm{~N}_{\text {bulk }}$ and $\delta^{15} \mathrm{~N}_{\text {pheo }}$ do not exhibit similar depth patterns (Fig. 6). This suggests that different processes govern these two records in soil. While $\delta^{15} \mathrm{~N}_{\text {bulk }}$ values become increasingly positive across the leaf-litter-soil continuum, pheo $a$ values remain centered around site average leaf values, and sometimes show slight decreases in value from leaf to litter and soil (Table 4). This suggests that mixing of inputs may account for litter and soil pheo $a \delta^{15} \mathrm{~N}$ values, while fractionating losses from the bulk soil $\mathrm{N}$ pool are required to explain $\delta^{15} \mathrm{~N}$ bulk values.

$\delta^{15} \mathrm{~N}_{\text {pheo }}$ of litter is a window into possible isotopic effects of decomposition on $\delta^{15} \mathrm{~N}_{\text {pheo }}$ of plant leaves. The difference between $\delta^{15} \mathrm{~N}_{\text {pheo }}$ of leaves and litter averaged close to zero and was substantially smaller than the difference in $\delta^{15} \mathrm{~N}_{\text {bulk }}$ $(0.3 \%$ versus $2.3 \%$ ), supporting greater isotopic fidelity along the decay continuum in pheo $a \delta^{15} \mathrm{~N}$ than bulk $\delta^{15} \mathrm{~N}$. Some of the site variability in isotopic offsets between litter and leaves/soil is likely due to differences in how well decomposed the collected litter was from site to site: at sites $\mathrm{C}$, $\mathrm{F}$, and $\mathrm{M}, \mathrm{C} / \mathrm{N}$ of litter is closer to that of vegetation than to soil, while at site I C/N of litter is closer to that of soil than to vegetation.

It is likely that litter samples do not reflect equal contributions from the plants sampled at the same site. Litter was collected from the surface of the soil pits, while vegetation was sampled from a radius of many meters, and plant taxa were not identified in litter samples to allow for source attribution. Soil algae and bacteria are considered insignificant contributors to soil pheo $a$, as the absorbance spectra of soil extracts showed that chlorophyll degradation products are dominated by higher plant contributions.

Pheophytin has two pathways of generation: like chlorophyll $a$, it is biosynthesized in plant leaves from glutamate where it serves as an electron acceptor in photosystem II (Klimov et al., 1977). Additionally, it is a product of chlorophyll degradation, whether via senescence, grazing, or decomposition across the leaf-soil continuum (Kräutler and Hörtensteiner, 2014; Sanger, 1971b), in which the central $\mathrm{Mg}$ is replaced by two $\mathrm{H}$ atoms. Transformation from chlorophyll to pheo $a$ involves breaking $\mathrm{N}-\mathrm{Mg}$ bonds, and so has potential for fractionation of $\mathrm{N}$ isotopes. However, the $\mathrm{N}-$ $\mathrm{Mg}$ bond is not a normal covalent bond, but a bond loosely connecting a ligand and metal in complex. Because the energy needed to break this bond is substantially smaller than the covalent bond, $\mathrm{Mg}$ loss from chlorophyll would theoretically be expected to have little or no $\mathrm{N}$ isotope fractionation. Senescence is unlikely to impart significant fractionation from bulk leaves given the observation that bulk leaf $\delta^{15} \mathrm{~N}$ does not change on abscission (Kolb and Evans, 2002) and the understanding that $\mathrm{N}$ contained in the tetrapyrrole structure of chlorophyll is not recycled by the plant (Eckhardt et al., 2004). However, fractionation on demetallation of chlorophyll to pheo $a$ has been observed in a laboratory setting with an effect of up to $2 \%$ (Sachs, 1997). Mineralization of pheo $a$ is unlikely to alter $\delta^{15} \mathrm{~N}$ of the remaining pheo $a$ pool because known products of chlorin defunctionalization retain the four atoms of tetrapyrrole $\mathrm{N}$ and their associated bonds (Keely, 2006).

It is unlikely that environmental changes that took place between production of litter and growth of current leaves explain the observed differences between $\delta^{15} \mathrm{~N}$ of plants and litter, given that litter at these sites is estimated to be no more than a few years old. Soil pools, however, could contain pheo $a$ that is considerably older. There is reason to expect that deeper pheo $a$ will be older than overlying pheo $a$ in soil profiles and increasing recognition that compounds can be preserved in the soil matrix much longer than their inherent lability would predict (Mikutta et al., 2006; Torn et al., 1997; Marin-Spiotta et al., 2011; Kramer et al., 2012).

While we do not know the age of the sampled soil pheo $a$, radiocarbon dates of 4130 and $8030 \mathrm{yr}$ BP were measured on soil organic carbon (SOC) deep within the soil profiles at sites A and D, respectively, along the climosequence (Chadwick et al., 2007), suggesting that our studied soils may reflect organic contributions from several thousands of years 
of soil development. Bulk soil carbon isotope values suggest that $\mathrm{C}_{4}$ pasture grasses, introduced over the last 200 hundred years, have been incorporated in the SOC in the top $40 \mathrm{~cm}$ of soil on these sites (Kelly et al., 1998a).

Patterns of radiocarbon $\left(\Delta^{14} \mathrm{C}\right)$ depletion of SOC in the profile (Baisden et al., 2002; Townsend et al., 1995; Tonneijck et al., 2006; Trumbore, 2009) indicate that SOC age increases with soil depth. Departures from this trend have been explained by the introduction of modern material by plant roots (Baisden et al., 2002), but as chlorophyll $a$ and pheo $a$ are photosynthetic pigments, we expect that inputs to the soil originate exclusively as litter accumulated at the soil surface, and we therefore expect for age of the chlorophyll derivatives to increase with depth. Bioturbation and episodic leaching could be disruptive of space-for-time trends, but based on the pattern observed in bulk SOC $\Delta{ }^{14} \mathrm{C}$ they are unlikely to interfere with millennial-scale patterns given appropriate vertical sampling distances. In fact, in aggrading profiles, bioturbation has been shown to contribute to the increase in SOC age with depth, by transporting SOC downward over short distances and migrating upwards as soil accumulates overhead (Tonneijck and Jongmans, 2008).

If down-profile $\delta^{15} \mathrm{~N}_{\text {pheo }}$ values did represent prior landscape $\delta^{15} \mathrm{~N}_{\text {leaf }}$ values, these data suggest greater changes to the $\mathrm{N}$ cycle at sites $\mathrm{F}$ and $\mathrm{I}$ than $\mathrm{C}$ and $\mathrm{M}$, which could reflect heavier grazing at sites $\mathrm{F}$ and I. Climate has been more constant throughout the Holocene at lower elevations than higher elevations on Kohala (Hotchkiss, 1998), which could further account for the relatively constant $\delta^{15} \mathrm{~N}_{\text {pheo }}$ values at site C.

If the total soil $\delta^{15} \mathrm{~N}$ pool reflects fractionation on loss of $\mathrm{N}$, but the soil $\delta^{15} \mathrm{~N}_{\text {pheo }}$ pool does not, we expect that the more important gaseous losses are relative to leaching losses at a site, and thus the higher $\delta^{15} \mathrm{~N}_{\text {bulk }}$ and the greater the offset between $\delta^{15} \mathrm{~N}_{\text {pheo }}$ and $\delta^{15} \mathrm{~N}_{\text {bulk }}$ will be. Environments where denitrification is more important relative to leaching tend to be dry environments, due to much smaller isotope effects of non-gaseous losses (Houlton and Bai, 2009), and drier sites do indeed have higher $\delta^{15} \mathrm{~N}$ in this study. Differences between $\delta^{15} \mathrm{~N}_{\text {pheo }}$ and $\delta^{15} \mathrm{~N}_{\text {bulk }}$ do not show clear trends along the climosequence, however. This could be due to the complexity of soil moisture at these sites, reflected in the variability in down-profile soil bulk $\delta^{15} \mathrm{~N}$.

Direct testing of the hypothesis of increasing age with depth of pheo $a$ would be enabled by improving the purification method of pheo $a$ from soil. Removing contaminating $\mathrm{C}$ would make stable or radiocarbon isotopes of pheo $a$ available tools to shed light on sources of pheo $a$ in soil profiles, age of the compounds, and what resolution change in $\mathrm{N}$ cycling over the temporal window provided by the chlorins depth profile is observable (Ishikawa et al., 2015). These questions could also be averted by measuring $\delta{ }^{15} \mathrm{~N}_{\text {pheo }}$ in soil profiles with constrained ages, such as buried horizons.

\subsection{Implications of the $\delta^{15} \mathrm{~N}_{\text {pheo }}$ proxy}

We suggest two key opportunities for application of a soilbased $\delta^{15} \mathrm{~N}_{\text {pheo }}$ proxy data to advance understanding of past terrestrial $\mathrm{N}$ dynamics. First, the ability to track changes in foliar $\delta^{15} \mathrm{~N}$ over time implies comparatively direct insight into factors affecting $\delta^{15} \mathrm{~N}$ of plants, notably the availability of nitrogen. Central questions concerning the timescale of $\mathrm{N}$ cycle responses to elevated $\mathrm{CO}_{2}$ concentration in the atmosphere, and whether availability of this limiting nutrient increases or decreases with climate change could be explored by selecting a time series that covers changes in atmospheric $p \mathrm{CO}_{2}$ (Goulden, 2016).

Second, comparison of compound-specific $\delta^{15} \mathrm{~N}_{\text {pheo }}$ with other $\delta^{15} \mathrm{~N}$ proxies over the same time domain could provide insights into processes that cause them to deviate from one another. Alternative sources of $\delta^{15} \mathrm{~N}$ proxies include subaqueous sediment deposits in lakes, ungulate tooth enamel, and bulk wood, black carbon, or soil. Deviations in records of $\delta^{15} \mathrm{~N}$ of pheo and tooth enamel at a common site would highlight changes in factors affecting dietary isotope fractionations, such as animal growth rates. $\delta^{15} \mathrm{~N}_{\text {pheo }}$ records could provide information on terrestrial sources of $\delta^{15} \mathrm{~N}$ relevant to aquatic sediment $\delta^{15} \mathrm{~N}$ records and allow aquatic and terrestrial signals to be distinguished. $\delta^{15} \mathrm{~N}_{\text {pheo }}$ could validate bulk proxy records, or highlight diagenetic limitations of the record. Within soil horizons, comparing $\delta^{15} \mathrm{~N}_{\text {pheo }}$ with $\delta^{15} \mathrm{~N}_{\text {bulk }}$ could provide information on both $\mathrm{N}$ availability to plants and dominant pathways of $\mathrm{N}$ loss, hydrologic or gaseous, at a site, allowing for comparison of multiple $\mathrm{N}$ cycle dynamics over time.

\section{Conclusions}

$\delta^{15} \mathrm{~N}_{\text {pheo }}$ in leaves provides a molecular recorder of foliar $\delta^{15} \mathrm{~N}$ and provides a means to trace leaf nitrogen signatures in litter and soils. The compound is found in litter and upper soil horizons in an abundance sufficient for isotopic analysis, where it shows greater fidelity to leaf $\delta^{15} \mathrm{~N}$ than does bulk material. $\delta^{15} \mathrm{~N}_{\text {pheo }}$ of soil may reveal temporal changes in nitrogen cycle behavior - e.g., the availability of nitrogen to plants, and whether nitrogen losses from the ecosystem had a dominant atmospheric or hydrologic fate. Due to the well-constrained photoautotrophic sources of chlorins, their lack of confounding heterotrophic enrichment, and their minimum $\mathrm{N}$ isotope fractionation during burial processes, CSIA of chlorins offers several advantages over bulk isotope analysis on the study of soil $\mathrm{C}$ and $\mathrm{N}$ cycles. $\delta^{15} \mathrm{~N}_{\text {pheo }}$ of soil is a most promising proxy for $\delta^{15} \mathrm{~N}_{\text {leaf }}$ where organic matter inputs are high and profiles aggrade. The potential to investigate decadal- to millennial-scale $\mathrm{N}$ cycle dynamics will depend largely on conditions for preservation of soil organic matter. 
Data availability. The data can be accessed by email request to the corresponding authors and have been submitted to the open-access database PANGAEA (data submission 1 August 2019, https://doi. pangaea.de/10.1594/PANGAEA.905053; Goulden et al., 2019).

Author contributions. SKEG and BZH acquired funding for the project. SKEG, BZH, and OC collected samples. NO, KHF, and BZH contributed laboratory space and materials. SKEG, NOO, HS, and YC conducted analyses of samples. SG performed data analysis, generated figures, and wrote the initial draft; $\mathrm{BZH}, \mathrm{NO}, \mathrm{KHF}$, $\mathrm{YC}, \mathrm{NOO}, \mathrm{HS}$, and $\mathrm{OC}$ contributed to the paper.

Competing interests. The authors declare that they have no conflict of interest.

Acknowledgements. We are grateful for help with sample collection received from the 2012 Hawaii Ecosystems meeting field campaign and Peter Vitousek. We are indebted to the following people for useful discussions, help with methods development, and support of project logistics: Stephie Kusch, Meytal Higgins, Kendra McLauchlan, Joe Craine, Troy Baisden, Yudzuru Inouye, Rota Wagai, Yoshinori Takano, Naoto Ishikawa, Dirk Holstege, Scott Morford, Alison Marklein, Joy Winbourne, Jens Stevens, Angie Mungia, Elizabeth Denis, Laurence Bird, and Sanjai Parikh. The 2010 "Isocamp" summer short course provided a forum for seminal discussions of this project. We thank the two anonymous reviewers for their thoughtful feedback on the manuscript.

Financial support. This research has been supported by the National Science Foundation Doctoral Dissertation Improvement Grant (grant no. 1311365), the National Science Foundation East Asia \& Pacific Summer Internship Program (grant no. 10246132), the National Science Foundation Inter-University Training for Continental Ecology Award (grant no. 1137336), the United States Environmental Protection Agency Science to Achieve Results (STAR) Fellowship (grant no. FP917327), and the National Science Foundation CAREER Award granted to Benjamin Z. Houlton (grant no. 1150246). Naohiko Ohkouchi and Nanako O. Ogawa were financially supported by the Japan Society for the Promotion of Science Fellowship (JSPS) (grant nos. 22244071 and 25281013).

Review statement. This paper was edited by Marcel van der Meer and reviewed by two anonymous referees.

\section{References}

Ainsworth, E. A. and Long, S. P.: What have we learned from 15 years of free-air $\mathrm{CO}_{2}$ enrichment (FACE)? A metaanalytic review of the responses of photosynthesis, canopy, New Phytologist, 165, 351-371, https://doi.org/10.1111/j.14698137.2004.01224.x, 2005.
Amundson, R., Austin, A. T., Schuur, E. A. G., Yoo, K., Matzek, V., Kendall, C., Uebersax, A., Brenner, D., and Baisden, W. T.: Global patterns of the isotopic composition of soil and plant nitrogen, Global Biogeochem. Cy., 17, 1, https://doi.org/10.1029/2002gb001903, 2003.

Baisden, W. T., Amundson, R., Brenner, D. L., Cook, A. C., Kendall, C., and Harden, J. W.: A multiisotope $\mathrm{C}$ and $\mathrm{N}$ modeling analysis of soil organic matter turnover and transport as a function of soil depth in a California annual grassland soil chronosequence, Global Biogeochem. Cy., 16, 1135, https://doi.org/10.1029/2001gb001823, 2002.

Bidigare, R. R., Kennicutt, M. C., Keeneykennicutt, W. L., and Macko, S. A.: Isolation and purification of chlorophyll-a and chlorophyll- $b$ for the determination of stable carbon and nitrogen isotope compositions, Analyt. Chem., 63, 130-133, 1991.

Brenner, D. L., Amundson, R., Baisden, W. T., Kendall, C., and Harden, J.: Soil $\mathrm{N}$ and ${ }^{15} \mathrm{~N}$ variation with time in a California annual grassland ecosystem, Geochim. Cosmochim. Ac., 65, 41714186, 2001.

Chadwick, O. A., Gavenda, R. T., Kelly, E. F., Ziegler, K., Olson, C. G., Elliott, W. C., and Hendricks, D. M.: The impact of climate on the biogeochemical functioning of volcanic soils, Chem. Geol., 202, 195-223, https://doi.org/10.1016/j.chemgeo.2002.09.001, 2003.

Chadwick, O. A., Kelly, E. F., Hotchkiss, S. C., and Vitousek, P. M.: Precontact vegetation and soil nutrient status in the shadow of Kohala Volcano, Hawaii, Geomorphology, 89, 70-83, https://doi.org/10.1016/j.geomorph.2006.07.023, 2007.

Chikaraishi, Y., Matsumoto, K., Ogawa, N. O., Suga, H., Kitazato, H., and Ohkouchi, N.: Hydrogen, carbon and nitrogen isotopic fractionations during chlorophyll biosynthesis in $\mathrm{C}_{3}$ higher plants, Phytochemistry, 66, 911-920, https://doi.org/10.1016/j.phytochem.2005.03.004, 2005.

Craine, J. M., Elmore, A. J., Aidar, M. P. M., Bustamante, M., Dawson, T. E., Hobbie, E. A., Kahmen, A., Mack, M. C., McLauchlan, K. K., Michelsen, A., Nardoto, G. B., Pardo, L. H., Penuelas, J., Reich, P. B., Schuur, E. A. G., Stock, W. D., Templer, P. H., Virginia, R. A., Welker, J. M., and Wright, I. J.: Global patterns of foliar nitrogen isotopes and their relationships with climate, mycorrhizal fungi, foliar nutrient concentrations, and nitrogen availability, New Phytologist, 183, 980-992, https://doi.org/10.1111/j.1469-8137.2009.02917.x, 2009.

Cuddihy, L. W. and Stone, C. P.: Alteration of native hawaiian vegetation effects of humans their activities and introductions, in: Alteration of Native Hawaiian Vegetation: Effects of Humans, Their Activities and Introductions, edited by: Cuddihy, L. W. and Stone, C. P., Xii + 138 p., University of Hawaii Press, Honolulu, Hawaii, USA, Illus. Maps. Paper, XII +,138P-XII + 138 pp., 1990.

Denman, K. L., Brasseur, G., Chidthaisong, A., Ciais, P., Cox, P. M., Dickinson, R. E., Hauglustaine, D., Heinze, C., Holland, E., Jacob, D., Lohmann, U., Ramachandran, S., da Silva Dias, P. L., Wofsy, S. C., and Zhang, X.: Couplings Between Changes in the Climate System and Biogeochemistry, Cambridge University Press, Cambridge, United Kingdom and New York, NY, USA, 2007.

Descolas-Gros, C. and Scholzel, C.: Stable isotope ratios of carbon and nitrogen in pollen grains in order to characterize plant functional groups and photosynthetic pathway types, 
New Phytologist, 176, 390-401, https://doi.org/10.1111/j.14698137.2007.02176.x, 2007.

Dilcher, D. L., Pavlick, R. J., and Mitchell, J.: Chlorophyll derivatives in middle eocene sediments, Science, 168, 1447, https://doi.org/10.1126/science.168.3938.1447, 1970.

Durán, J., Morse, J. L., Groffman, P. M., Campbell, J. L., Christenson, L. M., Driscoll, C. T., Fahey, T. J., Fisk, M. C., Likens, G. E., Melillo, J. M., Mitchell, M. J., Templer, P. H., and Vadeboncoeur, M. A.: Climate change decreases nitrogen pools and mineralization rates in northern hardwood forests, Ecosphere, 7, e01251, https://doi.org/10.1002/ecs2.1251, 2016.

Eckhardt, U., Grimm, B., and Hortensteiner, S.: Recent advances in chlorophyll biosynthesis and breakdown in higher plants, Plant Molecular Biology, 56, 1-14, https://doi.org/10.1007/s11103004-2331-3, 2004.

Enders, S. K., Pagani, M., Pantoja, S., Baron, J. S., Wolfe, A. P., Pedentchouk, N., and Nunez, L.: Compound-specific stable isotopes of organic compounds from lake sediments track recent environmental changes in an alpine ecosystem, Rocky Mountain National Park, Colorado, Limnol. Oceanogr., 53, 1468-1478, 2008.

Galloway, J. N., Schlesinger, W. H., Levy, H., Michaels, A., and Schnoor, J. L.: Nitrogen-fixation - anthropogenic enhancement - environmental response, Global Biogeochem. Cy., 9, 235-252, 1995.

Gerhart, L. M. and McLauchlan, K. K.: Reconstructing terrestrial nutrient cycling using stable nitrogen isotopes in wood, Biogeochemistry, 120, 1-21, https://doi.org/10.1007/s10533-014-99888,2014

Giambelluca, T. W., Nullet, M. A., and Schroeder, T. A.: Rainfall Atlas of Hawaii, Hawaii Department of Land and Natural Resources, Honolulu, Hawaii, 1986.

Gorham, E. and Sanger, J.: Plant pigments in woodland soils, Ecology, 48, 306, https://doi.org/10.2307/1933116, 1967.

Goulden, S. K. E.: Development and application of a new method to reconstruct terrestrial nitrogen cycling from isotopes of plant compounds in soil, PhD, Land, Air, \& Water Resources, University of California, Davis, 2016.

Goulden, S. K. E., Ohkouchi, N., Freeman, K. H., Chikaraishi, Y., Ogawa, N. O., Suga, H., Chadwick, O., and Houlton, B. Z.: Foliar, soil, litter, and chlorin data on carbon, nitrogen, and isotopes from a Hawaiian climosequence, PANGAEA, https://doi. pangaea.de/10.1594/PANGAEA.905053, 2019.

Handley, L. L., Azcon, R., Lozano, J. M. R., and Scrimgeour, C. M.: Plant delta N-15 associated with arbuscular mycorrhization, drought and nitrogen deficiency, Rapid Commun. Mass Sp., 13, 1320-1324, 1999.

Harbeck, M., Ritz-Timme, S., Schroeder, I., Oehmichen, M., and von Wurmb-Schwark, N.: Degradation of biomolecules: A comparative study on the diagenesis of DNA and proteins in human osseous tissue, Anthropologischer Anzeiger, 62, 387-396, 2004.

Hedges, J. I. and Oades, J. M.: Comparative organic geochemistries of soils and marine sediments, Org. Geochem., 27, 319-361, 1997.

Hietz, P., Dunisch, O., and Wanek, W.: Long-Term Trends in Nitrogen Isotope Composition and Nitrogen Concentration in Brazilian Rainforest Trees Suggest Changes in Nitrogen Cycle, Environ. Sci. Technol., 44, 1191-1196, https://doi.org/10.1021/es901383g, 2010.
Higgins, M. B., Robinson, R. S., Carter, S. J., and Pearson, A.: Evidence from chlorin nitrogen isotopes for alternating nutrient regimes in the Eastern Mediterranean Sea, Earth Planet. Sc. Lett., 290, 102-107, https://doi.org/10.1016/j.epsl.2009.12.009, 2010.

Hobbie, E. A. and Ouimette, A. P.: Controls of nitrogen isotope patterns in soil profiles, Biogeochemistry, 95, 355-371, https://doi.org/10.1007/s10533-009-9328-6, 2009.

Hodgson, G. W., Hitchon, B., Taguchi, K., Baker, B. L., and Peake, E.: Geochemistry of porphyrins, chlorins and polycyclic aromatics in soils, sediments and sedimentary rocks, Geochim. Cosmochim. Ac., 32, 737-772, 1968.

Hotchkiss, S. C.: Quaternary vegetation and climate of Hawai'i, University of Minnesota, St. Paul, Minnesota, 1998.

Houlton, B. Z. and Bai, E.: Imprint of denitrifying bacteria on the global terrestrial biosphere, P. Natl. Acad. Sci. USA, 106, 21713 21716, https://doi.org/10.1073/pnas.0912111106, 2009.

Houlton, B. Z., Sigman, D. M., Schuur, E. A. G., and Hedin, L. O.: A climate-driven switch in plant nitrogen acquisition within tropical forest communities, P. Natl. Acad. Sci. USA, 104, 89028906, https://doi.org/10.1073/pnas.0609935104, 2007.

Houlton, B. Z., Marklein, A. R., and Bai, E.: Representation of nitrogen in climate change forecasts, Nat. Clim. Change, 5, 398, https://doi.org/10.1038/nclimate2538, 2015.

Houlton, B. Z., Morford, S. L., and Dahlgren, R. A.: Convergent evidence for widespread rock nitrogen sources in Earth's surface environment, Science, 360, 58-62, https://doi.org/10.1126/science.aan4399, 2018.

Hungate, B. A., Dukes, J. S., Shaw, M. R., Luo, Y. Q., and Field, C. B.: Nitrogen and climate change, Science, 302, 1512-1513, https://doi.org/10.1126/science.1091390, 2003.

Hyodo, F. and Wardle, D. A.: Effect of ecosystem retrogression on stable nitrogen and carbon isotopes of plants, soils and consumer organisms in boreal forest islands, Rapid Commun. Mass Sp., 23, 1892-1898, https://doi.org/10.1002/rcm.4095, 2009.

Ishikawa, N. F., Yamane, M., Suga, H., Ogawa, N. O., Yokoyama, Y., and Ohkouchi, N.: Chlorophyll $a$-specific $\Delta^{14} \mathrm{C}, \delta^{13} \mathrm{C}$ and $\delta^{15} \mathrm{~N}$ values in stream periphyton: implications for aquatic food web studies, Biogeosciences, 12, 6781-6789, https://doi.org/10.5194/bg-12-6781-2015, 2015.

Junium, C. K., Keely, B. J., Freeman, K. H., and Arthur, M. A.: Chlorins in mid-Cretaceous black shales of the Demerara Rise: The oldest known occurrence, Org. Geochem., 42, 856-859, https://doi.org/10.1016/j.orggeochem.2011.04.002, 2011.

Keely, B. J.: Geochemistry of chlorophylls, in: Advances in Photosynthesis and Respiration, edited by: Grimm, B., Porra, R., Rudiger, W., and Scheer, H., Springer, ISBN 978-90-481-7140-8, 535-561 pp., 2006.

Kelly, E. F., Blecker, S. W., Yonker, C. M., Olson, C. G., Wohl, E. E., and Todd, L. C.: Stable isotope composition of soil organic matter and phytoliths as paleoenvironmental indicators, Geoderma, 82, 59-81, https://doi.org/10.1016/s00167061(97)00097-9, 1998a.

Kelly, E. F., Chadwick, O. A., and Hilinski, T. E.: The effect of plants on mineral weathering, Biogeochemistry, 42, 21-53, https://doi.org/10.1023/a:1005919306687, 1998 b.

Kennicutt, M. C., Bidigare, R. R., Macko, S. A., and Keeneykennicutt, W. L.: The stable isotopic composition of photosynthetic pigments and related biochemicals, Chem. Geol., 101, 235-245, 1992. 
Klimov, V., Klevanik, A., and Shuvalov, V.: Reduction of pheophytin in the primary light reaction of photosystem II, FEBS letters, 82, 183-186, 1977.

Kolb, K. J. and Evans, R. D.: Implications of leaf nitrogen recycling on the nitrogen isotope composition of deciduous plant tissues, New Phytologist, 156, 57-64, 2002.

Kramer, M. G., Sanderman, J., Chadwick, O. A., Chorover, J., and Vitousek, P. M.: Long-term carbon storage through retention of dissolved aromatic acids by reactive particles in soil, Global Change Biol., 18, 2594-2605, https://doi.org/10.1111/j.13652486.2012.02681.x, 2012.

Kräutler, B. and Hörtensteiner, S.: Chlorophyll breakdown: chemistry, biochemistry, and biology, in: Handbook of Porphyrin Science (Volume 28) With Applications to Chemistry, Physics, Materials Science, Engineering, Biology and Medicine - Volume 28: Chlorophyll, Photosynthesis and Bio-inspired Energy, World Scientific, 117-185, 2014.

Kusch, S., Kashiyama, Y., Ogawa, N. O., Altabet, M., Butzin, M., Friedrich, J., Ohkouchi, N., and Mollenhauer, G.: Implications for chloro- and pheopigment synthesis and preservation from combined compound-specific $\delta^{13} \mathrm{C}, \delta^{15} \mathrm{~N}$, and $\Delta^{14} \mathrm{C}$ analysis, Biogeosciences, 7, 4105-4118, https://doi.org/10.5194/bg7-4105-2010, 2010.

Luo, Y., Su, B., Currie, W. S., Dukes, J. S., Finzi, A. C., Hartwig, U., Hungate, B., McMurtrie, R. E., Oren, R., Parton, W. J., Pataki, D. E., Shaw, M. R., Zak, D. R., and Field, C. B.: Progressive nitrogen limitation of ecosystem responses to rising atmospheric carbon dioxide, Bioscience, 54, 731-739, 2004.

Marin-Spiotta, E., Chadwick, O. A., Kramer, M., and Carbone, M. S.: Carbon delivery to deep mineral horizons in Hawaiian rain forest soils, J. Geophys. Res.-Biogeo., 116, G3, https://doi.org/10.1029/2010JG001587, 2011.

Martinelli, L. A., Piccolo, M. C., Townsend, A. R., Vitousek, P. M., Cuevas, E., McDowell, W., Robertson, G. P., Santos, O. C., and Treseder, K.: Nitrogen stable isotopic composition of leaves and soil: Tropical versus temperate forests, Biogeochemistry, 46, 4565, 1999.

McLauchlan, K. K., Williams, J. J., Craine, J. M., and Jeffers, E. S.: Changes in global nitrogen cycling during the Holocene epoch, Nature, 495, 352-355, https://doi.org/10.1038/nature11916, 2013

Menge, D. N. L., Baisden, W. T., Richardson, S. J., Peltzer, D. A., and Barbour, M. M.: Declining foliar and litter delta ${ }^{15} \mathrm{~N}$ diverge from soil, epiphyte and input delta ${ }^{15} \mathrm{~N}$ along a $120000 \mathrm{yr}$ temperate rainforest chronosequence, New Phytologist, 190, 941952, https://doi.org/10.1111/j.1469-8137.2010.03640.x, 2011.

Meyers, P. A.: Organic geochemical proxies of paleoceanographic, paleolimnologic, and paleoclimatic processes, Org. Geochem., 27, 213-250, https://doi.org/10.1016/s0146-6380(97)00049-1, 1997.

Meyers, P. A. and Ishiwatari, R.: Lacustrine organic geochemistry - an overview of indicators of organic-matter sources and diagenesis in lake-sediments, Org. Geochem., 20, 867-900, https://doi.org/10.1016/0146-6380(93)90100-p, 1993.

Mikutta, R., Kleber, M., Torn, M. S., and Jahn, R.: Stabilization of soil organic matter: Association with minerals or chemical recalcitrance?, Biogeochemistry, 77, 25-56, https://doi.org/10.1007/s10533-005-0712-6, 2006.
Ogawa, N. O., Nagata, T., Kitazato, H., and Ohkouchi, N.: Ultrasensitive elemental analyzer/isotope ratio mass spectrometer for stable nitrogen and carbon isotope analysis, in: Earth, Life, and Isotopes, edited by: Ohkouchi, N., Tayasu, I., and Koba, K., Kyoto University Press, Japan, 339-353, 2010.

Overman, N. C. and Parrish, D. L.: Stable isotope composition of walleye: $\mathrm{N}-15$ accumulation with age and area-specific differences in delta C-13, Can. J. Fish. Aquat. Sci., 58, 1253-1260, 2001.

Porter, S. C.: Late Pleistocene eolian sediments related to pyroclastic eruptions of Mauna Kea volcano, Hawaii, Quaternary Res. 47, 261-276, https://doi.org/10.1006/qres.1997.1892, 1997.

Robinson, D.: delta N-15 as an integrator of the nitrogen cycle, Trends Ecol. Evol., 16, 153-162, 2001.

Sachs, J. P.: Nitrogen isotopes in chlorophyll and the origin of Eastern Mediterranean sapropels, Massachusetts Institute of Technology/Woods Hole Oceanographic Institution, Cambridge, Massachusetts, 1997.

Sachs, J. P. and Repeta, D. J.: Oligotrophy and nitrogen fixation during eastern Mediterranean sapropel events, Science, 286, 24852488, 1999.

Sanger, J. E.: Identification and Quantitative Measurement of Plant Pigments in Soil Humus Layers, Ecology, 52, 959-963, 1971a.

Sanger, J. E.: Quantitative investigations of leaf pigments from their inception in buds through autumn coloration to decomposition in falling leaves, Ecology, 52, 1075-1089, 1971 b.

Spengler, S. R. and Garcia, M. O.: Geochemistry of the Hawi lavas, Kohala volcano, Hawaii, Contrib. Mineral. Petr., 99, 90-104, https://doi.org/10.1007/bf00399369, 1988.

Sponheimer, M., Robinson, T., Ayliffe, L., Roeder, B., Hammer, J., Passey, B., West, A., Cerling, T., Dearing, D., and Ehleringer, J.: Nitrogen isotopes in mammalian herbivores: Hair delta N-15 values from a controlled feeding study, Int. J. Osteoarchaeol., 13, 80-87, https://doi.org/10.1002/oa.655, 2003.

Stevens, R. E. and Hedges, R. E. M.: Carbon and nitrogen stable isotope analysis of northwest European horse bone and tooth collagen, 40,000 BP-present: Palaeoclimatic interpretations, Quaternary Sci. Rev., 23, 977-991, https://doi.org/10.1016/j.quascirev.2003.06.024, 2004.

Stevens, R. E., Jacobi, R., Street, M., Germonpre, M., Conard, N. J., Munzel, S. C., and Hedges, R. E. M.: Nitrogen isotope analyses of reindeer (Rangifer tarandus), 45,000 BP to 900 BP: Palaeoenvironmental reconstructions, Palaeogeogr. Palaeocl., 262, 32-45, https://doi.org/10.1016/j.palaeo.2008.01.019, 2008.

Templer, P. H. and Dawson, T. E.: Nitrogen uptake by four tree species of the Catskill Mountains, New York: Implications for forest $\mathrm{N}$ dynamics, Plant Soil, 262, 251-261, https://doi.org/10.1023/b:plso.0000037047.16616.98, 2004.

Thackeray, F.: Late Quaternary palaeoclimates at Nelson Bay Cave, based on stable carbon and nitrogen isotope ratios from ungulate teeth: a re-assessment, S. Afr. J. Sci., 94, 442-443, 1998.

Thornton, P. E., Doney, S. C., Lindsay, K., Moore, J. K., Mahowald, N., Randerson, J. T., Fung, I., Lamarque, J.-F., Feddema, J. J., and Lee, Y.-H.: Carbon-nitrogen interactions regulate climate-carbon cycle feedbacks: results from an atmosphereocean general circulation model, Biogeosciences, 6, 2099-2120, https://doi.org/10.5194/bg-6-2099-2009, 2009.

Tonneijck, F. H. and Jongmans, A. G.: The influence of bioturbation on the vertical distribution of soil organic mat- 
ter in volcanic ash soils: a case study in northern Ecuador, Eur. J. Soil Sci., 59, 1063-1075, https://doi.org/10.1111/j.13652389.2008.01061.x, 2008.

Tonneijck, F. H., van der Plicht, J., Jansen, B., Verstraten, J. M., and Hooghiemstra, H.: Radiocarbon dating of soil organic matter fractions in Andosols in northern Ecuador, Radiocarbon, 48, 337-353, 2006.

Torn, M. S., Trumbore, S. E., Chadwick, O. A., Vitousek, P. M., and Hendricks, D. M.: Mineral control of soil organic carbon storage and turnover, Nature, 389, 170-173, 1997.

Townsend, A. R., Vitousek, P. M., and Trumbore, S. E.: Soil organic-matter dynamics along gradients in temperature and land-use on the island of hawaii, Ecology, 76, 721-733, https://doi.org/10.2307/1939339, 1995.

Treibs, A.: Chlorophyll and heme derivatives in organic mineral materials, Angewandte Chemie, 49, 0682-0686, 1936.

Trumbore, S.: Radiocarbon and Soil Carbon Dynamics, in: Annual Review of Earth and Planetary Sciences, Annual Review of Earth and Planetary Sciences, Annual Reviews, Palo Alto, 4766, 2009.

Tyler, J., Kashiyama, Y., Ohkouchi, N., Ogawa, N., Yokoyama, Y., Chikaraishi, Y., Staff, R. A., Ikehara, M., Ramsey, C. B., Bryant, C., Brock, F., Gotanda, K., Haraguchi, T., Yonenobu, H., and Nakagawa, T.: Tracking aquatic change using chlorine-specific carbon and nitrogen isotopes: The last glacial-interglacial transition at Lake Suigetsu, Japan, Geochem. Geophys. Geosyst., 11, Q09010, https://doi.org/10.1029/2010gc003186, 2010.
Vitousek, P. M. and Chadwick, O. A.: Pedogenic Thresholds and Soil Process Domains in Basalt-Derived Soils, Ecosystems, 16, 1379-1395, https://doi.org/10.1007/s10021-013-9690-z, 2013.

Vitousek, P. M. and Howarth, R. W.: Nitrogen limitation on land and in the sea - how can it occur, Biogeochemistry, 13, 87-115, 1991.

von Sperber, C., Chadwick, O. A., Casciotti, K. L., Peay, K. G., Francis, C. A., Kim, A. E., and Vitousek, P. M.: Controls of nitrogen cycling evaluated along a well-characterized climate gradient, Ecology, 98, 1117-1129, https://doi.org/10.1002/ecy.1751, 2017.

Wang, Y. P. and Houlton, B. Z.: Nitrogen constraints on terrestrial carbon uptake: Implications for the global carbon-climate feedback, Geophys. Res. Lett., 36, 24, https://doi.org/10.1029/2009gl041009, 2009.

Wedin, D. A., Tieszen, L. L., Dewey, B., and Pastor, J.: Cabonisotope dynamics during grass decomposition and soil organicmatter formation, Ecology, 76, 1383-1392, 1995.

Wolfe, E. W. and Morris, J.: Geologic Map of the Island of Hawaii, USGS Map I-2524-A, 1996.

Ziegler, K., Hsieh, J. C. C., Chadwick, O. A., Kelly, E. F., Hendricks, D. M., and Savin, S. M.: Halloysite as a kinetically controlled end product of arid-zone basalt weathering, Chem. Geol., 202, 461-478, https://doi.org/10.1016/j.chemgeo.2002.06.001, 2003. 